Article

\title{
Enantioselective epoxidation of olefins with hydrogen peroxide catalyzed by bioinspired aminopyridine manganese complexes derived from L-proline
}

\author{
Wenfang Wang a,b, Qiangsheng Sun a, Chungu Xia a , Wei Sun a,* \\ a State Key Laboratory for Oxo Synthesis and Selective Oxidation, Lanzhou Institute of Chemical Physics, Chinese Academy of Sciences, Lanzhou 730000, \\ Gansu, China \\ b University of Chinese Academy of Sciences, Beijing 100049, China
}

\section{A R T I C L E I N F O}

\section{Article history:}

Accepted 22 May 2018

\section{Keywords:}

Aminopyridine ligand

Manganese

Asymmetric epoxidation

Hydrogen peroxide

Olefin
Received 26 March 2018

Published 5 September 2018

\begin{abstract}
A B S T R A C T
Three chiral aminopyridine ligands derived from L-proline were prepared. Careful evaluation of the corresponding aminopyridine manganese complexes in asymmetric epoxidation of olefins revealed a broad substrate scope in the presence of $0.2 \mathrm{~mol} \%$ manganese complex and 0.5 equiv. 2,2-dimethylbutyric acid, with aqueous hydrogen peroxide as an oxidant. A variety of olefins including styrenes, chromenes, and cinnamamides were transformed successfully into the target epoxides with moderate to excellent enantioselectivity (yield up to $95 \%$, ee up to $99 \%$ ).
\end{abstract}

(C) 2018, Dalian Institute of Chemical Physics, Chinese Academy of Sciences. Published by Elsevier B.V. All rights reserved.

\section{Introduction}

Metalloenzymes can promote a wide range of oxidative transformations, such as hydroxylation, epoxidation, and cis-dihydroxylation. Inspired by the properties of metalloenzymes, researchers have established biomimetic synthetic metal (e.g., Mn, Fe) complexes coordinated with tetradentate nitrogen (N4) ligands as excellent catalysts in oxidation reactions in the past decades [1-4]. The landmark investigations of epoxidation of olefins by biomimetic N4 metal complexes were begun in 2001 by Jacobsen and co-workers [5]. They reported that an Fe(II)(mep) complex (mep $=N, N^{\prime}$-dimethyl- $N, N^{\prime}$-bis (2-pyridinylmethyl)ethane-1,2-diamine) could rapidly mediate the epoxidation of aliphatic alkenes with aqueous hydrogen peroxide as the oxidant; note that acetic acid served as an important additive in the iron catalytic system. Earlier in the same year, Que and co-workers [6] first demonstrated enantioselective cis-dihydroxylation of olefins catalyzed by the iron complex of the aminopyridine N4 ligand. In 2003, Mn-MCP-(OTf) 2 [MCP $=N, N$-dimethyl- $N, N$-bis(2-pyridylmethyl) cyclohexane-trans1,2-diamine] was used in the epoxidation of olefins with peracetic acid as an oxidant by Stack and co-workers; importantly, an ee of $10 \%$ was observed in the epoxidation of vinyl cyclohexane [7]. The development of novel elegant ligands is considered the key approach to obtaining highly efficient catalysts $[8,9]$. In this context, Costas [10-14], Talsi and Bryliakov [15-20], Gao [21,22], and our group [23-31] have developed many chiral N4 ligands, and their manganese and

\footnotetext{
* Corresponding author. Tel: +86-931-4968278; Fax: +86-931-4968129; E-mail: wsun@licp.cas.cn

This work was supported by the National Natural Science Foundation of China (21473226, 21773273), Key Research Program of Frontier Sciences, CAS (QYZDJ-SSW-SLH051), and Natural Science Foundation of Jiangsu Province (BK20170420).

DOI: 10.1016/S1872-2067(18)63116-X | http://www.sciencedirect.com/science/journal/18722067 | Chin. J. Catal., Vol. 39, No. 9, September 2018
} 
iron complexes exhibit good to excellent stereocontrol in the enantioselective epoxidation of various olefins (Scheme 1). Among them, the chiral N4 ligands derived from chiral 2,2'-bipyrrolidine play an important role in iron- or manganese-catalyzed asymmetric epoxidation of olefins (Scheme 1) [11,12,14,16-20]. However, these chiral 2,2'-bipyrrolidine skeletons are not easily available and are costly. In addition, the epoxidation catalyzed by manganese or iron complexes coordinated by these documented ligands requires a large quantity of acids as a vital additive [16,23]. It has been proposed that protonation of the hydroperoxide ligand by the coordinated carboxylic acid in metal-hydroperoxo intermediates facilitates 0-0 bond cleavage, generating high-valent metal-oxo species as reactive epoxidizing intermediates. Recently, Costas and co-workers reported that the quantity of carboxylic acid could be dramatically decreased to catalytic loading by including dimethylamino groups at the 4-position of the PDP ligand [Scheme 1, NMe2PDP, PDP = 2- $\{2-[1-$ (pyridin2-ylmethyl)-pyrrolidin-2-yl]pyrrolidin-1-yl\}methyl) pyridine] $[12,13]$. In 2012, we reported a series of facile N4 ligands (Scheme 1, S-PMP, S-PEB) derived from L-proline, which exhibited enantioselectivity comparable to those of chiral 2,2'-bipyrrolidine skeletons [28-32]. More importantly, L-proline is abundant in nature and easily transformed and diversified.

On the basis of our previous work, we hypothesized that modification of the substituents on the pyridyl groups and diamine backbone of the N4 ligand from L-proline would provide several new and practical N4 ligands. Herein, we report three structurally new aminopyridine ligands derived from L-proline and the catalytic performance of the corresponding manganese complexes in asymmetric epoxidation of a variety of olefins using aqueous hydrogen peroxide as an oxidant.

\section{Experimental}

\subsection{General}

The starting materials were purchased from commercial suppliers and used without further purification. ${ }^{1} \mathrm{H}$ NMR and ${ }^{13} \mathrm{C}$ NMR spectra were recorded on a Bruker Avance III 400 $\mathrm{MHz}$ spectrometer using $\mathrm{CDCl}_{3}$ as the solvent with tetramethylsilane as an internal reference. Gas chromatography-mass spectrometry (GC-MS) spectra were recorded on an Agilent Technologies 7890A GC system with an Agilent 5975 inert mass-selective detector (EI) and an HP-5MS column $(0.25 \mathrm{~mm}$ $\times 30 \mathrm{~m}$, film: $0.25 \mu \mathrm{m}$ ). High-performance liquid chromatography (HPLC) analysis was performed on a Waters-Breeze instrument (2487 Dual $\lambda$ absorbance detector and 1525 binary HPLC pump). Chiralpak OD-H, AS-H, and IC columns were purchased from Daicel Chemical Industries, Ltd. GC analysis was performed on an Agilent 6820 GC instrument with a CP-Chirasil-Dex CB column. Column chromatography was generally performed on silica gel (300-400 mesh), and thin-layer chromatography inspections were performed on silica gel $\mathrm{GF}_{254}$ plates.

L-proline-based diamines $\mathbf{1}$ and $\mathbf{2}$ were synthesized using a previously reported method $[28,29,33]$.

\subsection{Synthesis and characterization of ligands $\mathbf{L} \mathbf{1}-\mathbf{L} \mathbf{3}$}

For L1, $(S)$ - $N$-methyl-1-(pyrrolidin-2-yl)methanamine (1) $(2.1 \mathrm{mmol})$ and $30 \mathrm{~mL}$ of dichloromethane (DCM) were added to a $100-\mathrm{mL}$ round-bottom flask. Then $\mathrm{K}_{2} \mathrm{CO}_{3}$ (6 eq.) was added. Next, 2-(chloromethyl)- $N, N$-dimethylpyridin-4-amine (3) $(5.0$ mmol) was dissolved in $20 \mathrm{~mL}$ of DCM by addition through a constant-pressure dropping funnel at $0{ }^{\circ} \mathrm{C}$. Then the mixture

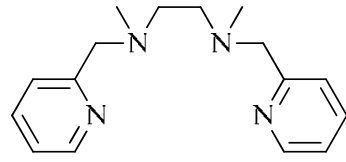

MEP

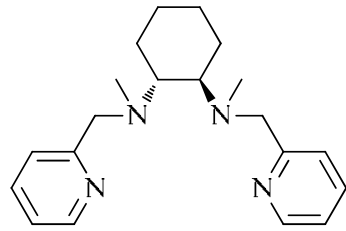

MCP

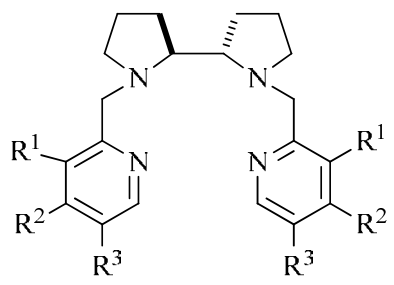

PDP: $\mathrm{R}^{1}=\mathrm{R}^{2}=\mathrm{R}^{3}=\mathrm{H}$

Me2NPDP: $\mathrm{R}^{1}=\mathrm{R}^{3}=\mathrm{H}, \mathrm{R}^{2}=\mathrm{Me}_{2} \mathrm{~N}$

${ }^{\text {dMM }}{ }_{\text {PDP: }} \mathrm{R}^{1}=\mathrm{R}^{3}=\mathrm{Me}, \mathrm{R}^{2}=\mathrm{OMe}$

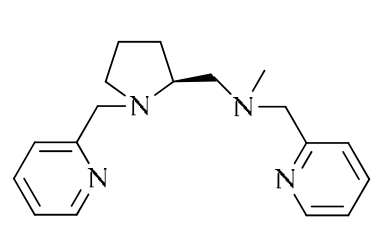

S-PMP

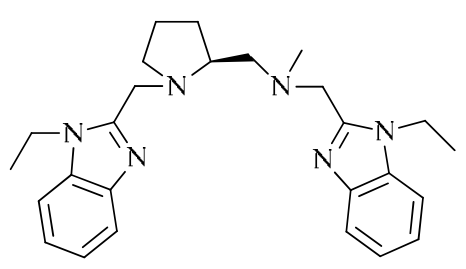

S-PEB<smiles>[Y]Cc1ncc(CNCC2CCCN2Cc2ncc([Y])c([R])c2[R])c([R])c1[Y]</smiles>

This work

$$
\begin{aligned}
& \text { L1: } R^{1}=M e, R^{2}=H, R^{3}=M_{2} N, R^{4}=H \\
& \text { L2: } R^{1}=B n, R^{2}=H, R^{3}=M_{2} N, R^{4}=H \\
& \text { L3: } R^{1}=M e, R^{2}=M e, R^{3}=M e O, R^{4}=M e
\end{aligned}
$$

Scheme 1. Tetradentate nitrogen (N4) ligands. 
was stirred in an ice bath for $1 \mathrm{~h}$ and gradually warmed to room temperature overnight. The mixture was then filtered, and the filter was washed with DCM. The combined filtrates were evaporated under reduced pressure. To the resulting residue, a solution of $\mathrm{NaOH}(2 \mathrm{~mol} / \mathrm{L})$ was added to adjust the $\mathrm{pH}$ to greater than 10 , and the mixture was extracted with $3 \times$ $20 \mathrm{~mL}$ of DCM. The combined organic phases were washed successively with saturated aqueous solutions of $\mathrm{NaCl}$ and $\mathrm{H}_{2} \mathrm{O}$. The organic phase was dried over anhydrous $\mathrm{Na}_{2} \mathrm{SO}_{4}$, and the solvent was removed under reduced pressure. The residue was purified by a silica column to yield the ligand $\mathbf{L 1}$ (330 mg, 41\%). ${ }^{1} \mathrm{H}$ NMR (400 MHz, $\left.\mathrm{CDCl}_{3}\right) \delta 8.10-7.94(\mathrm{~m}, 2 \mathrm{H}), 6.60(\mathrm{~d}, J$ $=8.0 \mathrm{~Hz}, 2 \mathrm{H}), 6.31(\mathrm{dd}, J=8.0,4.0 \mathrm{~Hz}, 2 \mathrm{H}), 4.17(\mathrm{~d}, J=12.0 \mathrm{~Hz}$, $1 \mathrm{H}), 3.50(\mathrm{dt}, J=28.0,16.0 \mathrm{~Hz}, 3 \mathrm{H}), 2.89(\mathrm{dd}, J=12.0,4.0 \mathrm{~Hz}$, $12 \mathrm{H}), 2.82(\mathrm{t}, J=8.0 \mathrm{~Hz}, 2 \mathrm{H}), 2.58-2.47(\mathrm{~m}, 1 \mathrm{H}), 2.39-2.25(\mathrm{~m}$, $2 \mathrm{H}), 2.21(\mathrm{~s}, 3 \mathrm{H}), 2.02-1.87(\mathrm{~m}, 1 \mathrm{H}), 1.7-1.51(\mathrm{~m}, 3 \mathrm{H}) .{ }^{13} \mathrm{C}$ NMR $\left(101 \mathrm{MHz} \mathrm{CDCl}_{3}\right) \delta 158.2,157.9,155.2,155.1,147.6,147.5$, 105.8, 105.4, 105.3, 105.2, 64.1, 62.5, 62.2, 60.9, 54.7, 43.2, 39.2, 39.1, 29.8, 23.0. High-resolution MS (HRMS) [electrospray ionization (ESI) MS] calcd. for $\mathrm{C}_{22} \mathrm{H}_{35} \mathrm{~N}_{6}[\mathrm{M}+\mathrm{H}]+:$ 383.2918, found: 383.2924 .

L2 was prepared using a method analogous to that used for L1 starting with (S)- $N$-benzyl-1-(pyrrolidin-2-yl) methanamine (2) $(2.1 \mathrm{mmol})$ and 2-(chloromethyl)- $N$, $N$-dimethylpyridin-4-amine (6) $(5.0 \mathrm{mmol})$ to provide a yellow oil (356 mg, 37\%). ${ }^{1} \mathrm{H}$ NMR (400 MHz, $\left.\mathrm{CDCl}_{3}\right) \delta 7.62(\mathrm{t}, J=4.0$ $\mathrm{Hz}, 4 \mathrm{H}), 7.43-7.12(\mathrm{~m}, 5 \mathrm{H}), 6.41(\mathrm{~d}, J=2.0 \mathrm{~Hz}, 1 \mathrm{H}), 6.34$ (dd, $J=$ 8.0, $4.0 \mathrm{~Hz}, 1 \mathrm{H}), 4.33$ (d, $J=8.0 \mathrm{~Hz}, 1 \mathrm{H}), 4.24-4.01(\mathrm{~m}, 2 \mathrm{H})$, $3.66-3.50(\mathrm{~m}, 3 \mathrm{H}), 2.99(\mathrm{~s}, 12 \mathrm{H}), 2.81(\mathrm{dd}, J=12.0,4.0 \mathrm{~Hz}, 2 \mathrm{H})$, 2.67 (dd, $J=12.0,8.0 \mathrm{~Hz}, 1 \mathrm{H}), 2.37$ (dd, $J=12.0,8.0 \mathrm{~Hz}, 1 \mathrm{H}$ ), 2.05-1.80 (m, 2H), 1.76-1.60 (m, 3H), 1.61-1.42 (m, 1H). ${ }^{13} \mathrm{C}$ NMR (101 MHz, $\left.\mathrm{CDCl}_{3}\right) \delta 156.1,155.3,143.2,132.1,130.2$, 128.8, 105.2, 104.7, 61.4, 59.1, 54.4, 53.5, 51.7, 51.3, 39.7, 29.1, 23.9. HRMS (ESI-MS) calcd. for $\mathrm{C}_{28} \mathrm{H}_{39} \mathrm{~N}_{6}[\mathrm{M}+\mathrm{H}]^{+}:$459.3231, found: 459.3218 .

L3 was prepared using a method analogous to that used for L1 starting with $(S)$ - $N$-methyl-1-(pyrrolidin-2-yl) methanamine (1) $\quad(2.1 \quad \mathrm{mmol})$ and 2-(chloromethyl)4-methoxy-3,5-dimethylpyridine (4) (5.0 mmol) to yield the ligand $\mathbf{L 3}$ (398 mg, 46\%). ${ }^{1} \mathrm{H}$ NMR (400 MHz, $\left.\mathrm{CDCl}_{3}\right) \delta 8.07$ (s, $2 \mathrm{H}), 4.04(\mathrm{~d}, J=12.0 \mathrm{~Hz}, 1 \mathrm{H}), 3.65(\mathrm{~d}, J=8.0 \mathrm{~Hz}, 6 \mathrm{H}), 3.46$ (dd, $J$ $=44.0,12.0 \mathrm{~Hz}, 3 \mathrm{H}), 2.76(\mathrm{~s}, 1 \mathrm{H}), 2.59(\mathrm{~s}, 1 \mathrm{H}), 2.36(\mathrm{dd}, J=12.0$, $4.0 \mathrm{~Hz}, 2 \mathrm{H}), 2.23(\mathrm{~s}, 3 \mathrm{H}), 2.19(\mathrm{~s}, 4 \mathrm{H}), 2.14(\mathrm{~s}, 5 \mathrm{H}), 2.11(\mathrm{~s}, 3 \mathrm{H})$, 2.03-1.78 (m, 2H), 1.63-1.49 (m, 2H), 1.48-1.37 (m, 1H). ${ }^{13} \mathrm{C}$ NMR (101 MHz, $\left.\mathrm{CDCl}_{3}\right) \delta 164.0,163.8,157.0,148.3,148.2$, $126.1,125.5,125.0,124.8,63.6,62.6,59.9,59.8,59.7,54.9,43.1$, 30.2, 22.6, 13.2, 10.9. HRMS (ESI-MS) calcd. for $\mathrm{C}_{24} \mathrm{H}_{37} \mathrm{~N}_{4} \mathrm{O}_{2}$ $[\mathrm{M}+\mathrm{H}]^{+}:$413.2911, found: 413.2905 .

\subsection{Synthesis and characterization of the manganese complexes $\boldsymbol{C 1}-\mathbf{C} 3$}

C1: $\mathrm{Mn}\left(\mathrm{CF}_{3} \mathrm{SO}_{3}\right)_{2}(0.25 \mathrm{mmol}, 1$ eq. $)$ was added to a stirred solution of chiral ligand $\mathbf{L 1}(0.25 \mathrm{mmol}, 1$ eq.) in acetonitrile ( 3 $\mathrm{mL}$ ) at room temperature. The reaction mixture was stirred for $24 \mathrm{~h}$. After drying under vacuum, the resulting solid was washed thoroughly with ether three times. It was then dried under vacuum to yield C1 (yield, >90\%). HRMS (ESI-MS) calcd. for $\mathrm{C}_{23} \mathrm{H}_{34} \mathrm{~F}_{3} \mathrm{MnN}_{6} \mathrm{O}_{3} \mathrm{~S}$ [M-OTf]

C2 was prepared using a method analogous to that used for C1 starting with $\mathbf{~} 2$ and $\mathrm{Mn}\left(\mathrm{CF}_{3} \mathrm{SO}_{3}\right)_{2}$ to obtain the product as a solid (yield, >90\%). HRMS (ESI-MS) calcd. for $\mathrm{C}_{29} \mathrm{H}_{38} \mathrm{~F}_{3} \mathrm{MnN}_{6} \mathrm{O}_{3} \mathrm{~S}$ [M-OTf] ${ }^{+}:$662.2058, found: 662.2070 .

C3 was prepared using a method analogous to that used for C1 starting with $\mathbf{L 3}$ and $\mathrm{Mn}\left(\mathrm{CF}_{3} \mathrm{SO}_{3}\right)_{2}$ to obtain the product as a solid (yield, >90\%). HRMS (ESI-MS) calcd. for $\mathrm{C}_{24} \mathrm{H}_{36} \mathrm{MnN}_{4} \mathrm{O}_{2}$ [M-20Tf] ${ }^{2+}:$ 233.6104, found: 233.6096.

\subsection{General procedures for asymmetric epoxidation}

In a typical reaction, a MeCN $(0.5 \mathrm{~mL})$ solution consisting of the substrate $(0.4 \mathrm{mmol})$, catalyst $(0.2 \mathrm{~mol} \%)$, and acid ( 0.5 eq.) was mixed in a $10-\mathrm{mL}$ flask at $-30{ }^{\circ} \mathrm{C}$. Then a $\mathrm{H}_{2} \mathrm{O}_{2}$ solution $(1.5$ eq., diluted from a $30 \%$ aqueous solution in $0.5 \mathrm{~mL}$ of $\mathrm{MeCN}$ ) was added via a syringe pump over $30 \mathrm{~min}$ with stirring at -30 ${ }^{\circ} \mathrm{C}$. The solution was further stirred at $-30{ }^{\circ} \mathrm{C}$ for $30 \mathrm{~min}$. At this point, decane was added to the mixture as an internal reference. The reaction was quenched with saturated $\mathrm{NaHCO}_{3}$ aqueous solution and saturated $\mathrm{Na}_{2} \mathrm{~S}_{2} \mathrm{O}_{3}$ aqueous solution and extracted with DCM; the sample was then investigated using GC and GC-MS analysis or purified by chromatography on silica gel to afford the epoxide product.

\section{Results and discussion}

The structure of a ligand is known to have an important effect on the activity of metal complex catalysts. In 2013, Costas and coworkers [12,34] reported that the electronic properties of a metal center could be tuned by introducing different substituents on the pyridine ring at the 4-position. In particular, a metal complex bearing dimethylamino groups on the ligand framework exhibited excellent activity (Scheme 1, Me2NPDP ligand). Further, Que and coworkers [35] captured a key oxoiron(V) intermediate with a 50\% yield, which was considered to be the active species in the oxidation reaction and was hard to synthesize and characterize, by introducing 4-methoxy-3,5-dimethylpyridine (dMM-pyridine) instead of pyridine donors into the tris(pyridine-2-ylmethyl)amine ligand. Recently, Wang and coworkers [36] also demonstrated, using density functional theory calculations, that an Fe(IV)-oxo cation radical species was generated when dimethylamino groups were introduced into PDP-Fe complex catalysts. These results indicated that using different substituents on ligands did change the spin state of the metal center and the activity of these metal complexes. Thus, we tried to synthesize three different tetradentate nitrogen ligands bearing strong electron-donating substituents (the $\mathrm{Me}_{2} \mathrm{~N}$ or $\mathrm{dMM}$ group) and the corresponding manganese complexes.

The aminopyridine ligands L1-L3 derived from L-proline were readily prepared, as shown in Scheme 2, and the manganese complexes were synthesized using the modified N4 ligands L1-L3 with $\mathrm{Mn}(\mathrm{OTf})_{2}$ and stirring in $\mathrm{CH}_{3} \mathrm{CN}$ at room temperature for $24 \mathrm{~h}$.

The activities of three structurally new catalysts were then 


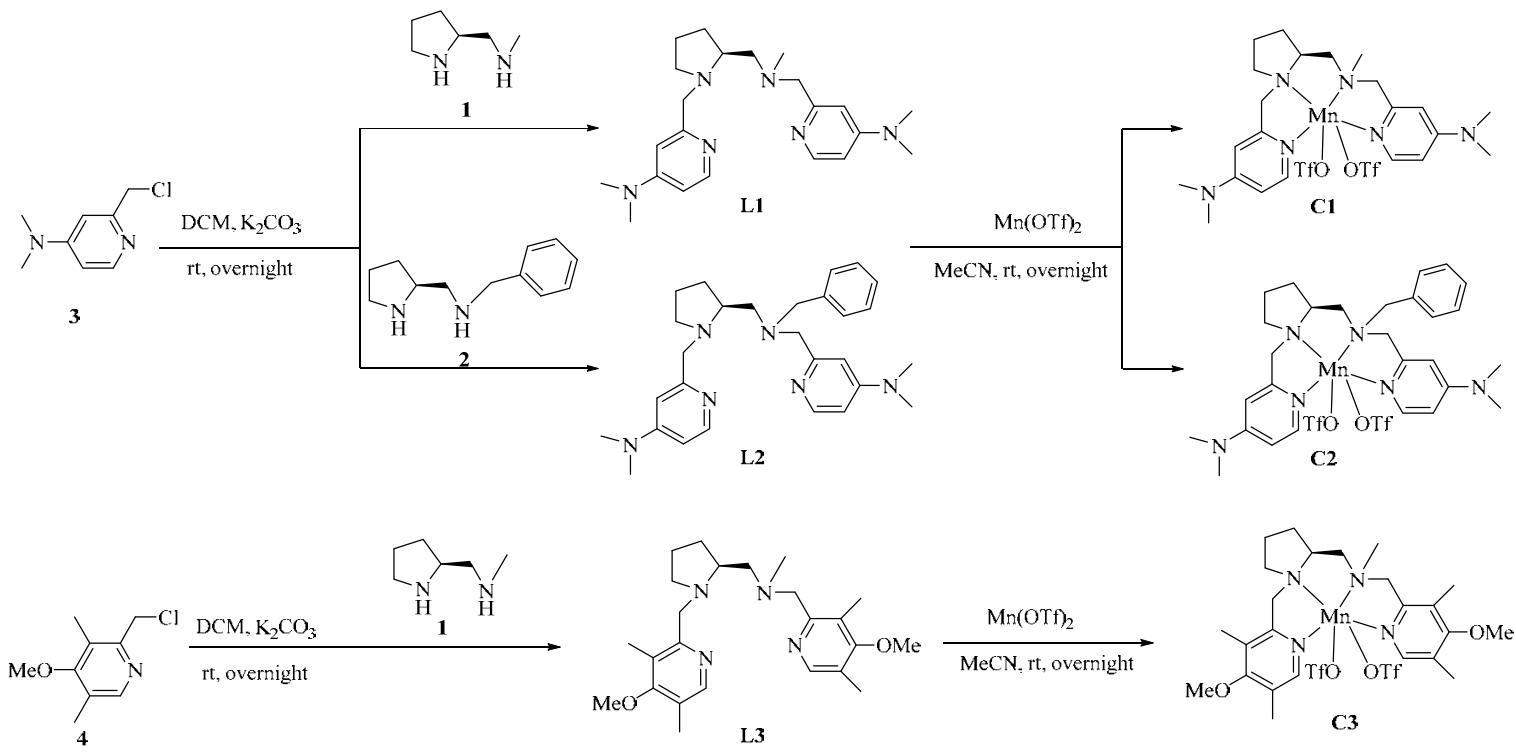

Scheme 2. Preparation of tetradentate nitrogen ligands derived from L-proline.

examined in asymmetric epoxidation. We selected cis- $\beta$-methylstyrene as a model substrate and used 2,2-dimethylbutanoic acid (DMBA) as the additive [26]. Epoxidation was performed in $\mathrm{CH}_{3} \mathrm{CN}$ at $-30{ }^{\circ} \mathrm{C}$ using $30 \%$ aqueous $\mathrm{H}_{2} \mathrm{O}_{2}$ (1.5 eq.) as the oxidant. It was shown that the catalyst $\mathbf{C 1}$ ( $0.1 \mathrm{~mol} \%$ ) was the most effective, furnishing epoxide in $84 \%$ yield and $82 \%$ ee (Table 1, entry 1 ). Surprisingly, the manganese catalyst $\mathbf{C 2}$, with a larger steric hindrance, exhibited decreased performance despite its richer electronic properties

Table 1

Reaction condition screening.

\begin{tabular}{|c|c|c|c|c|c|}
\hline & & $\begin{array}{l}\text { Mn compl } \\
30 \% \mathrm{H}_{2} \mathrm{O}_{2}(\end{array}$ & & & \\
\hline & & $\begin{array}{l}\text { Carboxylic } \\
\mathrm{CH}_{3} \mathrm{CN},-30^{2}\end{array}$ & $\begin{array}{l}\text { id } \\
30 \mathrm{~min}\end{array}$ & & \\
\hline Entry & $\begin{array}{c}\text { Cat. } \\
(x \mathrm{~mol} \%)\end{array}$ & $\begin{array}{c}\text { Acid } \\
(x \text { eq. })\end{array}$ & $\begin{array}{l}\text { Conv. } \\
(\%)\end{array}$ & $\begin{array}{c}\text { Yield a } \\
(\%)\end{array}$ & $\begin{array}{l}e^{e e^{b}} \\
(\%)\end{array}$ \\
\hline 1 & $\mathbf{1}(0.1)$ & DMBA(1.0) & 92 & 84 & 82 \\
\hline 2 & $2(0.1)$ & DMBA(1.0) & 66 & 41 & 82 \\
\hline 3 & $3(0.1)$ & DMBA(1.0) & 46 & 27 & 71 \\
\hline 4 & $\mathbf{1}(0.2)$ & $\operatorname{DMBA}(1.0)$ & 100 & 92 & 88 \\
\hline 5 & $1(0.2)$ & DMBA(0.5) & 100 & 90 & 89 \\
\hline 6 & $\mathbf{1}(0.2)$ & $D$-CРA(0.5) & 89 & 85 & 80 \\
\hline 7 & $\mathbf{1}(0.2)$ & HOAc(0.5) & 88 & 86 & 65 \\
\hline 8 & $\mathbf{1}(0.2)$ & 4-MHA(0.5) & 82 & 78 & 68 \\
\hline 9 & $\mathbf{1}(0.2)$ & PVA(0.5) & 92 & 93 & 80 \\
\hline 10 & $\mathbf{1}(0.2)$ & EHA(0.5) & 93 & 85 & 84 \\
\hline 11 & $\mathbf{1}(0.2)$ & $\operatorname{DMBA}(0.25)$ & 100 & 90 & 86 \\
\hline 12 & $\mathbf{1}(0.2)$ & $\operatorname{DMBA}(0.05)$ & 57 & 34 & 80 \\
\hline
\end{tabular}

Reaction conditions: cis- $\beta$-methylstyrene $(0.4 \mathrm{mmol})$, manganese complex (0.1-0.2 mol\%), $\mathrm{CH}_{3} \mathrm{CN}$ as a solvent $(0.5 \mathrm{~mL})$, DMBA (1.0 eq.), and $30 \% \mathrm{H}_{2} \mathrm{O}_{2}$ (1.5 eq.) in $0.5 \mathrm{~mL} \mathrm{MeCN}$ was added dropwise via a syringe pump over $30 \mathrm{~min}$ with stirring at $-30^{\circ} \mathrm{C}$ and then further stirring for $30 \mathrm{~min}$.

a The yield was determined by GC with decane as an internal standard.

${ }^{b}$ Determined by chiral GC.
(Table 1, entry 2). In addition, the manganese complex C3, with fewer electron-donating dMM groups, exhibited lower yield and enantioselectivity under the same conditions (Table 1, entry 3). To improve the conversion in epoxidation, a larger catalyst loading $(0.2 \mathrm{~mol} \%)$ was tested, and it was found that the substrate converted completely, and a $92 \%$ yield and $88 \%$ ee were obtained (Table 1, entry 4). The reaction proceeded well even in the presence of $50 \mathrm{~mol} \%$ DMBA when $0.2 \mathrm{~mol} \%$ manganese complex $\mathbf{C 1}$ was used (Table 1, entry 5).

In addition, the carboxylic acids also played an important role in the non-heme-metal-complex-promoted epoxidation by $\mathrm{H}_{2} \mathrm{O}_{2}$ because these reactions were achieved by the proposed "carboxylic-acid-assisted" 0-0 bond cleavage mechanism (Scheme 3) [16]. In 2016, Talsi and coworkers [20] studied the effect of carboxylic acids on the electronic structure of the intermediates in asymmetric epoxidation. They found that these acids with tertiary $\alpha$-carbon atoms displayed a smaller g-factor anisotropy, which resulted in higher enantioselectivities [20]. Very recently, we demonstrated that only the carboxylic acid binding on the manganese center can activate $\mathrm{H}_{2} \mathrm{O}_{2}$ to produce a presumed carboxylic $\mathrm{Mn}=\mathrm{O}$ (II) as the oxidizing reagent (Scheme 3). Thus, the carboxylic ligand coordinated on the manganese center could affect the stereocontrol of the asymmetric epoxidation [37]. In this context, we then evaluated the contribution of different carboxylic acids to this process. The results showed that DMBA was the best additive, giving a $90 \%$

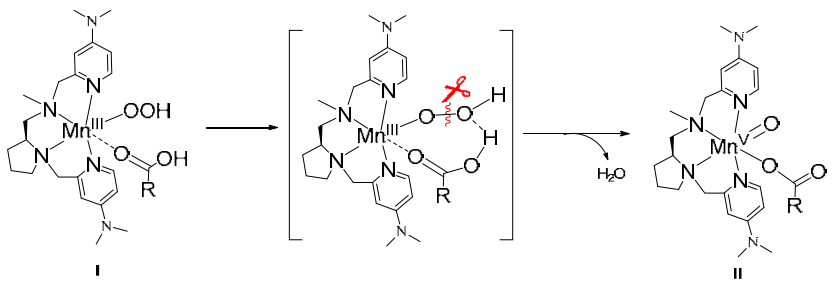

Scheme 3. Proposed mechanism of catalysis by tetradentate manganese complexes assisted by carboxylic acid. 
yield and $89 \%$ ee (Table 1, entry 5). Other acids, such as $D$-camphoric acid (D-CPA), acetic acid, 4-methylhexanoic acid

Table 2

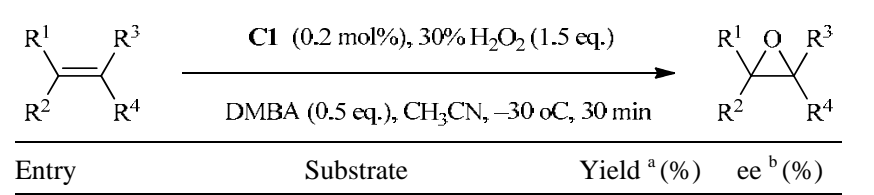

1

90

2<smiles>C=Cc1ccccc1</smiles>

66

62

3<smiles>C=Cc1ccc(C(F)(F)F)cc1</smiles>

90

64

67

61<smiles>C=Cc1ccc(Cl)cc1</smiles>

66

21

86

6<smiles>C(=C/c1ccccc1)\c1ccccc1</smiles>

33

7

8<smiles>N#CCCCCCCC#N</smiles><smiles>CC1(C)C=Cc2cc(C#N)ccc2O1</smiles>

93

98<smiles>CC1(C)C=Cc2cc([N+](=O)[O-])ccc2O1</smiles>

95

10

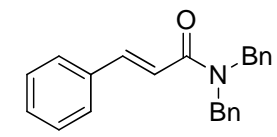

81

11<smiles>O=C(/C=C/c1ccc([N+](=O)[O-])cc1)N(Cc1ccccc1)Cc1ccccc1</smiles>

40

98

91<smiles>O=C(/C=C/c1ccc(Br)cc1)N(Cc1ccccc1)Cc1ccccc1</smiles>

13<smiles>O=C(/C=C/c1ccc(C(F)(F)F)cc1)N(Cc1ccccc1)Cc1ccccc1</smiles>

84 97
Substrate scope of olefins.
15<smiles>CN(C(=O)/C=C/c1ccccc1)c1ccccc1</smiles>

(4-MHA), pivalic acid (PVA), and 2-ethylhexanoic acid (EHA), resulted in lower ee values (Table 1, entries 6-10). Further lowering the acid loading degraded the performance (Table 1, entries 11 and 12).

After establishing the optimized conditions using the manganese complex $\mathbf{C 1}$, we investigated the generality of the reaction of different olefins. First, various styrenes were examined under the optimal conditions. Gratifyingly, styrenes bearing different substituents were transformed to epoxides successfully, albeit with moderate enantioselectivities (Table 2, entries 1-7). In addition, the epoxidation of stilbene compounds provided epoxides in low yield, but the enantioselectivity was quite good (Table 2, entries 6 and 7). To our delight, chromenes (Table 2, entries 8 and 9) and cinnamamides (Table 2, entries 10-15) were well-tolerated, and the target products were assembled with excellent enantioselectivities (up to 99\% ee).

\section{Conclusions}

In conclusion, we developed a series of novel tetradentate nitrogen ligands derived from L-proline. The corresponding manganese complexes were then prepared, and their catalytic activities and selectivities were evaluated in asymmetric epoxidation of olefins. Various olefins were transformed into epoxides successfully with low loading of the manganese catalyst together with aqueous $\mathrm{H}_{2} \mathrm{O}_{2}$ as the oxidant in the presence of a small amount of carboxylic acid as an additive. Notably, the enantioselective epoxidation of chromenes and cinnamamides provided the target products with excellent enantioselectivities (up to 99\% ee). Unlike the substituted PDP ligands, these N4 ligands were prepared from readily available and inexpensive amino acids, thus making the manganese catalysts more practical. Further utilization of these biomimetic manganese complexes in oxidation reactions is ongoing in our laboratory.

\section{Acknowledgments}

Technical assistance, material support, and other help or advice may be acknowledged briefly in this section (excluding financial support, which should appear in the footnote on the title page).

\section{References}

[1] E. P. Talsi, K. P. Bryliakov, Coord. Chem. Rev., 2012, 256, 1418-1434.

[2] K. P. Bryliakov, E. P. Talsi, Coord. Chem. Rev., 2014, 276, 73-96.

[3] O. Cusso, X. Ribas, M. Costas, Chem. Commun., 2015, 51, 14285-14298.

[4] C. X. Miao, C. G. Xia, W. Sun, Sci. Sin. Chim., 2014, 44, 1865-1875.

[5] M. C. White, A. G. Doyle, E. N. Jacobsen, J. Am. Chem. Soc., 2001, 123, 7194-7195.

[6] M. Costas, A. K. Tipton, K. Chen, D. H. Jo, L. Que Jr, J. Am. Chem. Soc., 2001, 123, 6722-6723.

Reaction conditions: substrate $(0.4 \mathrm{mmol}), \mathbf{C 1}(0.2 \mathrm{~mol} \%), \mathrm{CH}_{3} \mathrm{CN}$ as a solvent $(0.5 \mathrm{~mL})$, DMBA ( 0.5 eq.), and $30 \% \mathrm{H}_{2} \mathrm{O}_{2}$ (1.5 eq.) in $0.5 \mathrm{~mL}$ MeCN was added dropwise via a syringe pump over 30 min with stirring at $-30{ }^{\circ} \mathrm{C}$ and then further stirring for $30 \mathrm{~min}$.

a GC yield (entries 1-5) with decane as an internal standard, isolated yield (entries 6-15). b Determined by chiral GC or HPLC methods.
[7] A. Murphy, G. Dubois, T. D. P. Stack, J. Am. Chem. Soc., 2003, 125, 5250-5251.

[8] K. Chen, H. Xie, Chin. J. Catal., 2017, 38, 625-635.

[9] J. Q. Zhang, Y. S. Peng, W. G. Leng, Y. A. Gao, F. F. Xu, J. L. Chai, Chin. 


\title{
Graphical Abstract
}

Chin. J. Catal., 2018, 39: 1463-1469 doi: 10.1016/S1872-2067(18)63116-X

Enantioselective epoxidation of olefins with hydrogen peroxide catalyzed by bioinspired aminopyridine manganese complexes derived from $L$-proline

Wenfang Wang, Qiangsheng Sun, Chungu Xia, Wei Sun * Lanzhou Institute of Chemical Physics, Chinese Academy of Sciences; University of Chinese Academy of Sciences

Three tetradentate nitrogen ligands derived from L-proline were developed, and the catalytic activities and selectivities of the corresponding manganese complexes were carefully evaluated in asymmetric epoxidation of olefins.

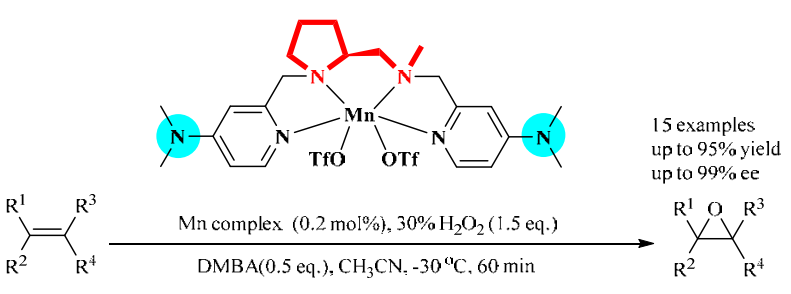

3622-3625.

[24] M. Wu, C. X. Miao, S. F. Wang, X. X. Hu, C. G. Xia, F. E. Kühn, W. Sun, Adv. Synth. Catal., 2011, 353, 3014-3022.

[25] C. X. Miao, B. Wang, Y. Yong, C. G. Xia, Y. M. Lee, W. W. Nam, W. Sun, J. Am. Chem. Soc., 2016, 138, 936-943.

[26] D. Y. Shen, B. Qiu, D. Q. Xu, C. X. Miao, C. G. Xia, W. Sun, Org. Lett., 2016, 18, 372-375.

[27] C. X. Miao, X. B. Yan, D. Q. Xu, C. G. Xia, W. Sun, Adv. Synth. Catal, 2017, 359, 476-484.

[28] B. Wang, C. X. Miao, S. F. Wang, F. E. Kühn, C. G. Xia, W. Sun, J. Organomet. Chem., 2012, 715, 9-12.

[29] B. Wang, C. X. Miao, S. F. Wang, C. G. Xia, W. Sun, Chem. Eur. J., 2012, 18, 6750-6753.

[30] B. Wang, S. F. Wang, C. G. Xia, W. Sun, Chem. Eur. J., 2012, 18, $7332-7335$.

[31] D. Y. Shen, C. X. Miao, S. F. Wang, C. G. Xia, W. Sun, Eur. J. Inorg. Chem., 2014, 2014, 5777-5782.

[32] B. Qiu, D. Q. Xu, Q. S. Sun, C. X. Miao, Y. M. Lee, X. X. Li, W. Nam, W. Sun, ACS Catal., 2018, 8, 2479-2487.

[33] Q. Zhu, H. Shen, Z. Yang, H. Ji, Chin. J. Catal., 2016, 37, 1227-1234.

[34] I. Prat, A. Company, T. Corona, T. Parella, X. Ribas, M. Costas, Inorg. Chem., 2013, 52, 9229-9244.

[35] W. N. Oloo, K. K. Meier, Y. Wang, S. Shaik, E. Münck, L. Que, Nat. Commun., 2014, 5, 3046.

[36] F. Wang, W. Sun, C. Xia, Y. Wang, J. Biol. Inorg. Chem., 2017, 22, 987-998.

[37] J. Y. Du, C. X. Miao, C. G. Xia, Y. M. Lee, W. Nam, W. Sun, ACS Catal., 2018, 8, 4528-4538.

\section{脯氨酸衍生的胺基吡啶四氮锰配合物催化双氧水参与的烯烃不对称环氧化反应}

\author{
王文芳 ${ }^{\mathrm{a}, \mathrm{b}}$ ，孙强盛 ${ }^{\mathrm{a}}$, 夏春谷 ${ }^{\mathrm{a}}$, 孙 伟 ${ }^{\mathrm{a},}$ \\ a 中国科学院兰州化学物理研究所羰基合成与选择氧化国家重点实验室, 甘肃兰州730000 \\ b国科学院大学, 北京100049
}

摘要: 自然界中存在许多的金属酶, 它们参与促进各种各样的氧化反应, 例如羟化反应, 环氧化反应等. 金属酶催化的反应 具有催化效率高、反应条件温和、选择性高等优点. 受大自然中的金属酶结构及其性质的启发, 人们提出了仿生催化氧化 的理念, 并开始对金属酶进行模拟, 致力于发展清洁氧化的反应方式. 在过去的几十年中, 科学家们设计合成了一系列仿 生金属配合物催化剂。例如, 利用非手性的乙二胺骨架设计合成出四齿氮配体 MEP ( $N, N^{\prime}-$ dimethyl$N, N^{\prime}$-bis(2-pyridinylmethyl)ethane-1,2-diamine), 将其制备成相应的铁配合物催化剂, 该铁催化剂可以很好的实现脂肪族烯 烃的环氧化, 产率高达 $90 \%$. 2003年, Stack小组首次报道了利用手性 $N, N$-二甲基环己二胺骨架衍生的四齿氮配体金属配合 
物Mn-MCP-(OTf $)_{2}(\mathrm{MCP}=N, N$-dimethyl- $N, N$-bis(2-pyridylmethyl)cyclohexane-trans-1,2-diamine)催化的不对称环氧化反应. 该反应的对映选择性仅仅为 $10 \%$. 因此, 发展新型手性四氮配体金属配合物, 用于高产率、高对映选择性的不对称环氧化反 应, 值得进行深入研究.

近年来发展的一些含手性二胺骨架的四齿氮配体，例如 PDP (2-[[2-(1-(pyridin-2-ylmethyl)-pyrrolidin2-yl)pyrrolidin-1-yl]methyl]pyridine), 被应用到不对称环氧化反应中, 但是其手性二胺骨架为联吡咯, 价格昂贵, 难以制备. 这在很大程度上限制了其在不对称合成中的实际应用. 因此, 利用一些易于合成的手性二胺骨架, 发展结构新颖、催化性 能优良的四氮金属配合物, 成为实现高效、高选择性不对称环氧化反应的关键.

在之前的工作基础上, 本文以简单易得、价格低廉的天然氨基酸—L- - 脯氨酸为起始原料, 选取吡啶环和含取代基的 吡啶环作为侧基氮供体, 制备了三种手性四齿氮配体. 随后, 我们利用新发展的手性四齿氮配体, 合成了相应的锰配合物, 并且分别将其运用于烯烃不对称环氧化反应中, 仔细评估了这些锰金属配合物的催化性能. 建立了以 $0.2 \mathrm{~mol} \%$ 的锰配合物 为催化剂, 0.5 当量的 2,2 二二甲基丁酸为添加剂, $30 \%$ 双氧水为氧化剂, 反应温度为 $-30{ }^{\circ} \mathrm{C}$, 乙腈为溶剂的催化不对称环氧化 反应体系. 反应结果显示: 该催化剂催化的不对称环氧化反应底物适用性广泛, 其中苯乙烯、苯并吡喃、烯酰胺等化合物 均可以被成功地转化为相应的环氧化物, 得到中等至优异的对映选择性(产率最高可达 $95 \%$, 对映选择性最高可达 $99 \%$ ).

关键词: 胺基吡啶配体; 锰; 不对称环氧化; 双氧水; 烯烃

收稿日期: 2018-03-26. 接受日期: 2018-05-22. 出版日期: 2018-09-05.

*通讯联系人. 电话: (0931)4968278; 传真: (0931)4968129; 电子信箱: wsun@licp.cas.cn

基金来源：国家自然科学基金(21473226, 21773273); 中国科学院前沿科学重点研究项目(QYZDJ-SSW-SLH051); 江苏省自然科 学青年基金项目(BK20170420).

本文的电子版全文由Elsevier出版社在ScienceDirect上出版(http://www.sciencedirect.com/science/journal/18722067). 